\title{
ASSESSMENT OF SOME BIOCHEMICAL INDICES IN FISHES FROM TWO DIFFERENT PARTS OF RIVERS STATE, NIGERIA
}

M. 0. WEGWU, B. W. ABBEY and G. O. IBEH

(Received 15 Jane 2000); Revision accepted 2 March, 2001)

\section{ABSTRACT}

Oreachromis niloticus (tilapia) and Chrysichthys nigrodigitatus (Catfish) sampled from Alakiri river in Rivers State, Nigeria, were examined for some biochemical indices and blood serum enzymes activities to assess the effects of environmental stress on fish health. The results were compared with those of Omuhuechi river (baseline) in Rivers State, Nigeria, The activity of Aspartate - aminotransferase (AST), Alanineaminotransferase (ALT) and Alkaline phosphatase (ALP) in Alakiri fish samples varied significantly ( $P \leq 0.05$ ) from those obtained from the base-line zone. Although, Albumin, Total Cholesterol and High Density Lipoprotein (HDL) Cholesterol levels in O. niloticus did not differ significantly, total protein and glucose levels showed marked variations in samples from the two rivers. Such variation were also evident in the levels of total protein, glucose, albumin and HDL - Cholesterol in C. nigrodigitatus. The high levels of the biochemical indices in fishes (tilapia and catfish) collected from Alakiri rivers suggests that constant discharge of industrial effluents into the aquatic environment has an adverse effect on the health of aquatic fauna.

KEY WORDS: Assessment, Biochemical Indices, Oreochromis Niloticus, Chrysicthys Nigrodigitatus.

\section{INTRODUCTION}

Clinical tests are available in human medisine to determine the general state of healin, evaluate the physiological effect of onvironmental toxicants, and to diagnose specific diseases. Some of the methods have been adapted for use with fish blood (Blaxhall, 1972). The need for establishing normal biochemical indices in fish with a view to aiding in the diagnosis of diseases (Hesser, 1960 ) and in connection with pollution and its effect (Mawdesley - Thomas, 1971) has been stressed.

Pollution of the aquatic environment as a direct consequence of increase in urbanization, activities of oil exploring and exploiting industries, among others, in Nigeria, has been the subject of concern, in recent times (Horsfall et al, 1998). For instance, the discharge of water containing ammonia from a fertilizer company into Okrika river, in Rivers State, Nigeria, resulted in massive killing of fish and greatly affected the aquatic life (Horsfall and Spiff, 1999). Alakiri aquatic environment is of great economic importance to Nigeria as several oil fields are located within the environment. Wegwu (1999) reported high levels of Mercury, Lead, Cadmium, Copper. Chromium and Iron in the surface water, sediment and muscles of fishes from the river and attributed it to the increased industrial activities in the area arising from oil exploration and exploitation.

Industrial activities in Omuhuechi (base - line) river are absent and its environment is still in its natural, virgin state. This work attempts to ascertain the health of $O$. niloticus and $C$. - nigrodigitatus exposed to industrial pollution by determining the levels of some biochemical indices and enzymes activities often employed in pathophysiological investigations. 


\section{MATERIALS AND METHODS}

\section{O. niloticus (tilapia) and $C$. nigrodigitatus} (catfish) were caught from Alakiri and Omuhuechi rivers, and transported to the laboratory. The fishes were introduced into holding tanks containing water from the rivers. The temperature of the water was maintained at $28 \pm 2^{\circ} \mathrm{C}$ and the fishes were fed with commercial fish diet purchased from Aqua culture, Aluu for 24 hours. This was to enable the fishes from the two rivers adapt to the holding tank environment prior to collection of blood. Ten (10) fish for each of the respective species, were selected randomly from the tanks. The fish were carefully netted, avoiding stress as much as possible and immediately anaesthetized in a trough containing aerated water and $150 \mathrm{mg} / \mathrm{l}$ Lignocaine (Rotex medica - GMBH). When inactivated, the fish were weighed, using the Fuji weighing batance and $3 \mathrm{~m} / \mathrm{s}$ of blood was drawn in disposable, plastic syringes by cardiac puncture. The needle was removed, and the blood gentiv expressed into a bottle containing anticoagulant (fluoride - oxalate) and into a dry, anti-coagulant - free plastic container, and mixed. Plasma separation was performed by centrifugation using MSEMinor 35 model of centrifuge. The weight of the fish fell within the ranges: $150 \mathrm{~g}-$ $200 \mathrm{~g}$ (for tilapia) and $230 \mathrm{~g}$ to $350 \mathrm{~g}$ (for catfishl.

Total protein was determined using the Biuret method (Garry and Williams, 1977) while the estimation of serum albumin was performed by the Bromocresol green (BCG) binding method (Cheesbrough, 1987). The Glucose - Oxidase - Peroxidase method, described by Baker and Silverton (1985) for the estimation of Glucose was adopted. Aspartate - aminotransferase (ALT) (E.C. 2.6.1.1), Alanine - aminotransferase (ALT) (E.C. 2.6.1.2) and cholesterol estimations were performed using commercial test kits (Randox). Alkaline phosphatase (E.C. 3.1.3.1) and high density Lipoprotein (HDL) cholesterol were respectively determined by the phenolphthalein monophosphate method and dextran sulphate -mg (11) method (Quimica, Clinica applicada-test kits). All determinations were carried out simultaneously with the same blood sample. The spectrophotometric technique (cam spec, $\mathrm{m} 201)$ was used in the estimation of parameters. The enzyme activities were expressed in international units (I.U). Also, the t- test was used in the statistical analysis of the results.

\section{RESULTS}

Table 1 illustrates the average plasma total protein, albumin, total cholestrol, high glucose values in $O$. niloticus caught from the Alakiri and Omuhuechi rivers. Broad ranges and high co-efficient of variations were recorded for all the biochemical indices in Alakiri and Omuhuechi fish plasina. There was no evidence of the influence of weight on the values of the biochemical indices obtained in this study. Also, statistical differences $(P \leq 0.05)$ in the means of plasma albumin, total cholesterol and $\mathrm{HDL}$ - cholesterol in $O$. niloticu. from the two rivers were insignificant. However, significant differences in their means existed in the plasma total protein and glucose levels. As shown in Table 2, with the exception of total cholesterol, marked statistical differences $(P \leq 0.05)$. existed in

TABLE L: LEVELS OF SOME BIOCHEMICAL INDICLS IN OREOCHROMIS NILOTICUS FROM ALAKIRI AND OMIHUECHI WATERS

\begin{tabular}{|c|c|c|c|c|c|c|}
\hline Parameler & Fish weight $(g)$ & $\begin{array}{l}\text { No. of } \\
\text { fish }\end{array}$ & Range & Muan & (TI) & C.V $(\% / 1)$ \\
\hline Total protein $(\mathrm{g} / \mathrm{l})$ & $\begin{array}{l}160-220 \\
(150-200)\end{array}$ & $\begin{array}{l}10 \\
(10)\end{array}$ & $\begin{array}{l}34.00-84.00 \\
(23.00-55.00)\end{array}$ & $\begin{array}{l}48.70^{\circ} \\
(33.70)^{\prime \prime}\end{array}$ & $\begin{array}{l}15.46 \\
(9.26)\end{array}$ & $\begin{array}{l}31.75 \\
(27.48)\end{array}$ \\
\hline Albumin $(\mathrm{g} / \mathrm{l})$ & $\begin{array}{l}160-220 \\
(150-200)\end{array}$ & $\begin{array}{l}10 \\
109\end{array}$ & $\begin{array}{l}10.00-28.00 \\
(7.00-40.00)\end{array}$ & $\begin{array}{l}21.70^{a} \\
(15.20)^{a}\end{array}$ & $\begin{array}{l}6.88 \\
(6.89)\end{array}$ & $\begin{array}{l}31.71 \\
(45.33)\end{array}$ \\
\hline Total Cholcsterol (mmol/L) & $\begin{array}{l}160-220 \\
(150-200)\end{array}$ & $\begin{array}{l}10 \\
(10)\end{array}$ & $\begin{array}{l}3.30-25.00 \\
(3.10-5.70)\end{array}$ & $\begin{array}{l}8.46^{n} \\
(4.06)^{n}\end{array}$ & $\begin{array}{l}7.29 \\
(0.85)\end{array}$ & $\begin{array}{l}86.17 \\
(20.94)\end{array}$ \\
\hline HDL-Cholesterol (mmol/L) & $\begin{array}{l}160-220 \\
(150-200)\end{array}$ & $\begin{array}{l}10 \\
(10)\end{array}$ & $\begin{array}{l}2.20 .7 .60 \\
(2.00-3.80)\end{array}$ & $\begin{array}{l}4.85^{\mathrm{a}} \\
(2.85)^{\mathrm{a}}\end{array}$ & $\begin{array}{l}3.63 \\
(0.67)\end{array}$ & $\begin{array}{l}74.85 \\
(23.51)\end{array}$ \\
\hline Glucose (mmol/L) & $\begin{array}{l}160-220 \\
(150-200)\end{array}$ & $\begin{array}{l}10 \\
(10)\end{array}$ & $\begin{array}{l}3.90-46.20 \\
(2.00-6.60) \\
\end{array}$ & $\begin{array}{l}17.68^{\mathrm{a}} \\
(33.70)^{\mathrm{b}}\end{array}$ & $\begin{array}{l}12.49 \\
(1.61)\end{array}$ & $\begin{array}{l}70.64 \\
(47.77) \\
\end{array}$ \\
\hline
\end{tabular}

* Values in parenthesis, are those of the unpoliued samples from Omuhuechi river.

* Means with differene superscripts are significantly different at the $95 \%$ conlifdence limif 
IABIN 2:

LEVEAS OF SOAW BOCHEMICAI, INDICIS IN CHRYSICHTHYS

NIGRODIGTATUS PROM ALAKIRI AND OMUIUHCOII WATLRS

\begin{tabular}{|c|c|c|c|c|c|c|}
\hline Parameler & Fish weight $(g)$ & $\begin{array}{l}\text { No. of } \\
\text { lish }\end{array}$ & Range & Mean & s(1) & $C \vee(\%)$ \\
\hline Total protein $(\mathrm{g} / \mathrm{l})$ & $\begin{array}{l}2.30-350 \\
(250-310)\end{array}$ & $\begin{array}{l}10 \\
(10)\end{array}$ & $\begin{array}{l}30.00(0.48 .00 \\
(19.00-32.00)\end{array}$ & $\begin{array}{l}38.60^{\circ} \\
\left(25.9(0)^{11}\right.\end{array}$ & $\begin{array}{l}5.58 \\
(5.53)\end{array}$ & $\begin{array}{l}14.46 \\
(21.35)\end{array}$ \\
\hline Albunin $(g / 1)$ & $\begin{array}{l}230-350 \\
(250-310)\end{array}$ & $\begin{array}{l}10) \\
(10)\end{array}$ & $\begin{array}{l}8.00-15.00 \\
(6.00-11.00)\end{array}$ & $\begin{array}{l}12.00^{6} \\
(8.10)^{6}\end{array}$ & $\begin{array}{l}2.45 \\
(2.201\end{array}$ & $\begin{array}{l}20.42 \\
(24.94)\end{array}$ \\
\hline Total Cholesterol (mmol/l.) & $\begin{array}{l}230-350 \\
(250-310)\end{array}$ & $\begin{array}{l}10 \\
(10) \\
\end{array}$ & $\begin{array}{l}4.60-6.10 \\
(4.10-6.00)\end{array}$ & $\begin{array}{l}7.50^{\circ} \\
(5.04)^{11}\end{array}$ & $\begin{array}{l}0.49 \\
(0.72)\end{array}$ & $\begin{array}{l}6.53 \\
(14.29)\end{array}$ \\
\hline HDL-Cholesterol (mmol/h) & $\begin{array}{l}230-350 \\
(250 \cdot 310)\end{array}$ & $\begin{array}{l}10 \\
(10)\end{array}$ & $\begin{array}{l}3.10-4.10 \\
(2.20-4.40)\end{array}$ & $\begin{array}{l}4.74^{\mathrm{n}} \\
(2.88)^{\mathrm{n}}\end{array}$ & $\begin{array}{l}2.42 \\
(0.71)\end{array}$ & $\begin{array}{l}51.05 \\
(31.14)\end{array}$ \\
\hline Glucose (minol/L) & $\begin{array}{l}230-350 \\
(250)-310)\end{array}$ & $\begin{array}{l}10 \\
(10)\end{array}$ & $\begin{array}{l}3.80-34.60) \\
(2.50-6.70)\end{array}$ & $\begin{array}{l}15.81^{11} \\
(4.48)^{\prime \prime}\end{array}$ & $\begin{array}{l}12.06 \\
(1.38) \\
\end{array}$ & $\begin{array}{l}76.28 \\
(30.80)\end{array}$ \\
\hline
\end{tabular}

* Means with the same superseripts are not dillerent at the P $\leq 0.05 \mathrm{kevel}$

Yalues in parenthesis are those of the un-polluted sample from Omuhuchi river.

MBLE 3: LEVELS OF BI,OOD SERLM ENXYMES IN OREOCHROMIS NILOTICUS IIROM ALAKIRI AND OMUHUECII WATERS

\begin{tabular}{|c|c|c|c|c|c|c|}
\hline Parameter & Fish weight $(\mathrm{g})$ & $\begin{array}{l}\text { No. of } \\
\text { fish }\end{array}$ & Range & Mean & $\mathrm{STO}$ & C.V $(\%)$ \\
\hline $\begin{array}{l}\text { AST } \\
(U / L)\end{array}$ & $\begin{array}{l}160-220 \\
(150-200)\end{array}$ & $\begin{array}{l}10 \\
(10)\end{array}$ & $\begin{array}{l}25.00-98.50 \\
(5.50-39.20)\end{array}$ & $\begin{array}{l}43.29^{11} \\
(16.77)^{b}\end{array}$ & $\begin{array}{l}25.27 \\
(10.24)\end{array}$ & $\begin{array}{l}58.37 \\
(61.00)\end{array}$ \\
\hline $\begin{array}{l}\text { ALT } \\
(U / L)\end{array}$ & $\begin{array}{l}160-220 \\
(150-200)\end{array}$ & $\begin{array}{l}10 \\
(10)\end{array}$ & $\begin{array}{l}20.4(0-132.10 \\
(3.40-39.00)\end{array}$ & $\begin{array}{l}51.99^{n} \\
(16.83)^{13}\end{array}$ & $\begin{array}{l}33.99 \\
(11.97)\end{array}$ & $\begin{array}{l}65.38 \\
(71.12)\end{array}$ \\
\hline $\begin{array}{l}\pi l I^{\prime} \\
(U / \mathrm{L})\end{array}$ & $\begin{array}{l}160-220 \\
(150-200)\end{array}$ & $\begin{array}{l}10 \\
(10)\end{array}$ & $\begin{array}{l}17.00-222.00 \\
(5.50-127.00)\end{array}$ & $\begin{array}{l}71.49^{11} \\
(24.12)^{11}\end{array}$ & $\begin{array}{l}60.40 \\
(36.53)\end{array}$ & $\begin{array}{l}84.40 \\
(151.45)\end{array}$ \\
\hline
\end{tabular}

TABLE 4: LEVLLS OF BLOOD SERUN ENZYMISS IN CHRYSICHTHYS NIGRODIGITATUS FROM ALAKIRI AND OMUIUECHI WATERS

\begin{tabular}{|l|l|l|l|l|l|l|}
\hline Parameter & Fish weight (g) & $\begin{array}{l}\text { No. of } \\
\text { fisli }\end{array}$ & Range & Mean & S TD & C.V(\%) \\
\hline AST & $230-350$ & 10 & $11.80-55.00$ & $25.06^{\mathrm{a}}$ & 13.28 & 52.99 \\
$(\mathrm{U} / \mathrm{L})$ & $(250-310)$ & $(10)$ & $(3.80-30.80)$ & $(13.60)^{\mathrm{b}}$ & $(9.85)$ & $(72.11)$ \\
\hline ALT & $230-350$ & 10 & $10.40-58.90$ & $22.21^{\mathrm{a}}$ & 13.87 & 62.45 \\
$(\mathrm{U} / \mathrm{L})$ & $(250-310)$ & $(10)$ & $(2.30-33.30)$ & $(9.47)^{\mathrm{b}}$ & $(8.82)$ & $(93.14)$ \\
\hline ALP & $230-350$ & 10 & $11.50-132.3$ & $39.78^{\mathrm{a}}$ & 35.89 & 90.22 \\
$(\mathrm{U} / \mathrm{L})$ & $(250-310)$ & $(10)$ & $(3.50-38.50)$ & $(13.88)^{\circ}$ & $(10.03)$ & $(72.26)$ \\
\hline
\end{tabular}

* Values in parenthesis are those of the unpolluted samples.

Means with different superseripts are significantly different at the $P \leq 0.05$ level.

the levels of plasma protein and HDL Cholesterol in 0 . nigrodigitatus - collected from the two rivers. Apart from plasma protein and total cholesterol in $O$. nigrodigitatus obtained from Alakiri river, other parameters gave co-efficient of variations above $20 \%$.

Results of the activities of blood serum enzymes in $O$. niloticus and $C$. nigrodigitatus caught from Alakiri and Omuhuechi rivers, are shown in Tables 3 and 4: Broad ranges and higher percentages of coefficient of variations were recorded for serum AST, ALT, and ALP activities in the two species of fish from the rivers. Also, statistical differences $(P \leq 0.05)$ existed in the activities of these enzymes in the fishes from the two rivers, with those from Omuhuechi river consistently showing lower values.

\section{DISCUSSION}

The wide range in values recorded for the biochemical indices and nzymes activities in the fishes from the study area may be attributed to various factors which significantly alter biochemical : parameters. These factors would include diet sources and availability, strain, age, sex, level of exposure to toxic substances, season and sexual maturity (McCarthy et al, 1973). Barnhart (1969) compared levels of haematological parameters such as haemoglobin levels, packed cell volume, 


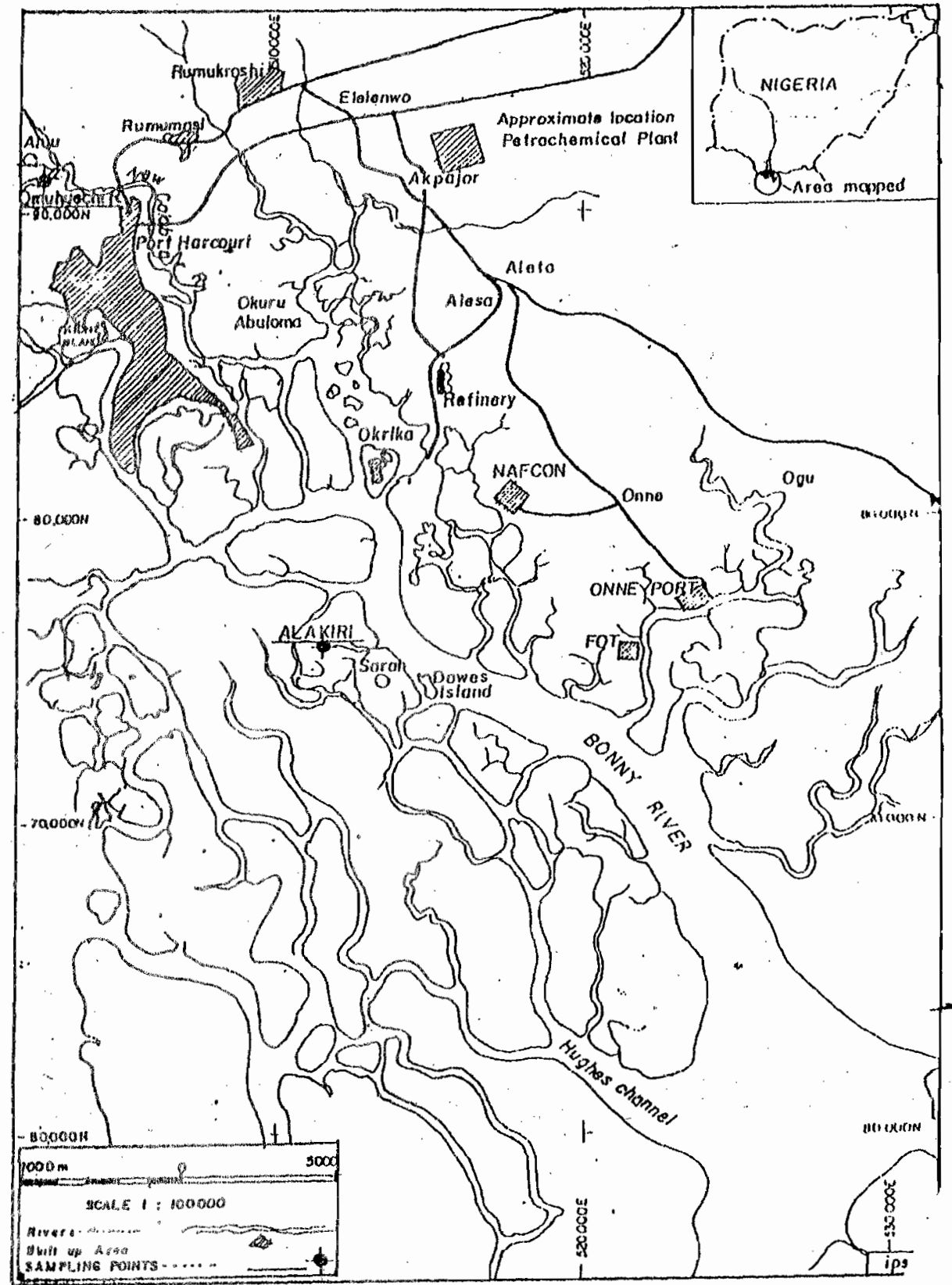

Figh. PORT HARCOURT SNO ITS ENVIRONS SHOWING THE SAMPLING POINTS

erythrocyte sedimentation rate and full blood count in rainbow trouts collected from a control pond and the wild. The control pond samples was defined within a narrow range while the wild type gave extremely wide range. Aasma total protein levels, which is biochemically accepted as an indicator of nutritional status (McCarthy el al: 1973) showed sigmiticant difference in O. niloticus serum from Alakiri and Omuhuechi rivers. Similar variation existed in the mean protein values of $C$. nigrodititatus samples from the two locations. A comparison of Jastial total protein in this study with thosdysdraingd by McCarthy et al. 11973) on rainbow trout $(40-68 \mathrm{~g} / \mathrm{l})$ indicated higher values in $O$. niloticus sampled from Alakiri river (34.0 - 84.0gll), Table 1. Serum albumin levels in $C$. nigrodigitatus obtained from Alakiri river varied significantly $(P \leq 0.05)$ from those of Omuhuechi river. Such variations were not observed inthe serum albumin of $O$. niloticus caught from the two rivers. Garry and William (1977). showed that too low plasma total protein :in fish indicate infectious disease, kidney' damage and nutritional imbalance and too high value indicate haemo-concentration and impaired water balance. Also, too low plasma cholesterol in 
fish is indicative of impaired lipid metabolism while too high values is a sign of ifish that is under chronic stress and dietary lipid imbalance. As shown in Tables 1 and 2, there was no significant difference in the levels of total cholesterol in $O$. niloticus and $C$. nigrodigitatus from the two locations. Although, HDL - cholesterol levels in 0 . niloticus and $C$. nigrodigitatus showed very close ranges, marked statistical variation was evident in the HDL - Cholesterol levels for C. nigrodigitatus caught from Alakiri and Omuhuechi rivers.

Low glucose levels indicate inanition while too high level is indicative of acute or chronic stress in fish. (Garry and William, 1977). As is evidenced in Tables 1 and 2 , concentration of plasma glucose in the two species of fish from the polluted (Alakiri) and baseline (Omuhuechi) rivers showed significant variations. The disparity in the means recorded for plasma glucose level indicate that the fishes in Alakiri river are under severe stress. Heat and Pritchard (1965) demonstrated hyperglycaemia in bluegill, lepomis macrochirius, subjected to short term hypoxia and correlated the increase in blood glucose with a decrease in liver glycogen. The selection of serum enzyme assays for the diagnosis of hepatic disease has been based on sufficient experience in correlating the serum values with other measures of hepatic function and disease to assure adequate sensitivity and specificity. These considerations have led to the wide. spread adoption of ALP, AST and ALT for the diagnosis of hepatic arro rolated diseases (John, 1979). To ascertain, if decisive disturbances of the equilibrium in the internal environment of fishes in Alakiri river existed, plasma ALT, AST and ALT activities were investigated. As shown in Tables 3 and 4. the extremely high values of MLT in both species of fish from Alakiri rivers as opposed to the control IOrmuluochi) and the significant levels of AST and AL in Alakiri sarnoles suggest the existence of

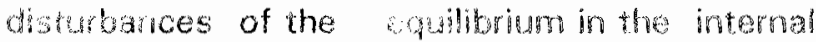
amvironment of fishes in Alakiri river. Racicot at al (1975) reported high lavels of these encrmes in Salmo garring rith exposed to Cols. They concluded that fish liver was more easily attacked oy the chemical. Generally the " hign values of biochemical indice and increased enzymes activities recorded for the fish caugnt Trom Alakin river, as opposed to those of Omuhuechı river with lower values, would indicate that constant discharge of wastes into the rivers has detrimental effects on the health of fish.

\section{ACKNOWLEDGEMENT}

The authors wish to express their profound gratitude to Elder Boniface Chuku, Dr. E. O. Ayalogu and Mr. Tracy Huber, for their financial assistance and valuable suggestions during the course of this work.

\section{REFERENCES}

Baker, F.J. and Silverton, R. E., 1985. Introduction 10 Medical Laboratory Technology. $6^{\text {th }}$ E.D. Butterworths London. $126 \mathrm{pp}$.

Barnhart, R. A., 1969. Effects of certain variables on haematological characteristics of rainbow trout. Trans Amd. - Fish Soc: 98: 411-418.

Blaxhall P.C. , 1972. The haematological assessment of the health of freshwater fish. A review of selected literature. J. Fish Biol.; 4: 593-604.

Cheesbrought, M., 1987. Medical Laboratory manual for tropical countries $2^{\text {nd }}$ Ed. Butterworth-Heinemann London. pp. $509-511$.

Garry, A W. and William, T. Y., 1977. Clinical Method for the assessment effects of environmental stress on fish health. Technical papers of the U.S Fish and Wild-life Service. Washington D.C. $48 \mathrm{pp}$.

Heat, A. G. and Pritchard, A. W. 1965. Effects of severe hypoxia on Carbohydrate energy store and metabolism in two species of freshwater fisl. Physiol. Zvol. 38: 325 - 334 .

Horsfall, Jnr. M. and Spiff, A. 1. 1999. Principles of environment chemistry. Metroprints Limited, Nigeria. 127-134 Pp.

Horsfall Jnr. M., Howard, I. C., and Spiff, A. I., 1998. Tissue distribution of heavy metals in mudskipper (Penophthalmus Papillio) from the mangrove swamps of the Coastal New Calabar Rivers. Nigeria. JASEM. I: $50-53$.

Hesser, E. F. 1960. Methocis for routine fish haematology. Progriefish cult; 22: 164-171.

Jolnn, B. H. , 1979. Clinical diagnosis and Management by Laboratory methods. $16^{\text {th }}$ Ed. Saunder, W. B. Comp. Philadlphina, London. 4-7 Pp

K.lontz, G. W. and Smith, L. S., 1968. Methods of using fish as biological research subjects. In: Methods of animal experimentation (Ed. Gay, W. R.) Academic Press London. 35-7 Pp.

Mawdeslay - Thomas, L. E. 1971. Toxic Chemical - the risk to fish. New Scient. 49: 74.

McCarthy, D. H; Stevenson, I. P. and Roberts, M. S., 1973 . Some blood paraincters of rainbow trout (Salmo 
Jairtineri (Richandson), The kanilogps variely. I. Hisly Biol. 5: 1-8.

Racicot. J. G., Gaudet, M., and Leray, C., 1975. Blood and Liver cnzymes in minbow trou (Salmo sair(heri Rich) with emphosis on their diagnostic use: study of ("Clat toxicity and a case of acromonas Infection. I. Hish B3io, 7: 82.3 833
Wegwu, M. O. 1909. Seasonal varialions of pollutants in sonte areas of the Niger Detta and their toxicity on some aquatic taum. Ph.b. thesis Biochemistry Dept. University of Port Harcontrt. PP. 197-228. 